Bentham open
CrossMark
Content list available at: www.benthamopen.com/TOCIEJ/
DOI: $10.2174 / 1874149501610010489$

RESEARCH ARTICLE

\title{
Spatio-temporal Effect of Urbanization on Surface Water Bodies: A Method of RS and GIS
}

\author{
Jianfeng Zhu ${ }^{1}$, Qiuwen Zhang ${ }^{1,}$, Zhong Tong ${ }^{2}$, Xiaofei Liu ${ }^{1}$ and Fei Yan ${ }^{1}$

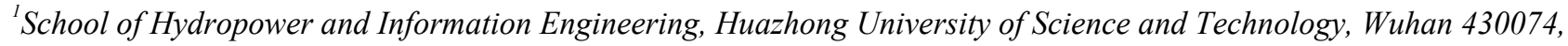 \\ China \\ ${ }^{2}$ China Communications Construction Company Second Harbor Consultants Co.,Ltd., Wuhan 430074, China
}

Received: January 15, 2016

Revised: March 17, 2016

Accepted: May 28, 2016

\begin{abstract}
This paper focuses on the spatio-temporal effects of urbanization on surface water resources in Wuhan, China. Specifically, the relationships between surface water bodies and their surrounding land use changes are discussed quantitatively by remote sensing (RS) and geographic information system (GIS). In this paper, surface water bodies and land use classifications in 1991 and 2005 are detected from Landsat TM/ETM+ images. On this basis, the area changes of water bodies and their transformations are extracted by overlap analysis. The result proves that most of the reduced surface water bodies had transformed into developed land in the urban districts. Finally, a comparative analysis indicates that the rate of increment of developed land in $100 \mathrm{~m}$ buffer (14\%) is higher than in $1000 \mathrm{~m}$ buffer (8.8\%). In other words, urban development is growing towards water bodies as urbanization. Therefore, the effects of urbanization on surface water bodies can be summarized as follows: (1) water bodies are likely to be occupied directly by developed land with urbanization; (2) the space of surface water is compressed due to urban expansion. This paper would provide a suggestion for urban planners and water resource managers.
\end{abstract}

Keywords: Geographic information system, Land use change, Remote sensing, Surface water, Urbanization, Wuhan.

\section{INTRODUCTION}

Over the past 30 years, urbanization has been improved significantly in China [1]. Especially in some large cities, population has increased sharply, and the real estate industry has become more prosperous. So the cities have expanded rapidly. At the same time, the rapid development put heavy pressures on ecology, resource and environment for the cities. For example, some extreme phenomena of water resources, such as water shortage, water pollution and urban stormwater, occur more frequently [2 - 6]. These problems are hindering the development of the cities and people's lives. Surface water resource is an important part of urban water resources. It not only can provide the water supplies for productions and livings, but also would be useful for communities in regulating micro-climate and enhancing the capacity of flood storage [7]. In this paper, we focus on the spatio-temporal effect of urbanization on surface water resources in Wuhan, China. It would be very significant for water resources protection.

In terms of land use and cover change (LUCC), urbanization could be reflected in that urban land, such as residence and commercial land, is increasing. Researches about LUCC have been studied extensively. A part of researches focused on monitoring land use changes and modeling urban expansion by remote sensing (RS) and geographical information system (GIS).For instance, Zheng systematically investigated the conservation and recovery of grassland and forestland in Sichuan Province by CBERS II [8]; Du proposed a method to monitor urban impervious surface area change using CBERS images and one scene of HJ-1 image [9]; Abdullahi and Pradhan evaluated the mixed land use for Kajang City based on GIS [10]; and Razavi combined artificial neural network with Markov chain model to predict the

\footnotetext{
* Address correspondence to this author at the School of Hydropower and Information Engineering, Huazhong University of Science and Technology, Wuhan 430074, China; Tel: +86 278754 3992; Fax: +86 278754 3992; E-mail: qwzhang@hust.edu.cn
} 
trend of LUCC in Kermanshah City [11]. Some other researchers put emphasis on climatic and environmental changes due to urban development. Dale proved that there are some implied linkages between land use, climate change and energy [12]. Deng reviewed the impacts of LUCC on regional climate and discussed regional climate models in the development of agricultural land and urban land [13]. Lei and Radhi analyzed the urban heat island effect with urbanization and LUCC based using RS in Xuzhou, China and Bahrain respectively [14, 15].

In recent years, the effects of urbanization on water resources have been concerned widely. For example, Huang, Hettiarachchi and Chen indicated that urbanization led to a reduction in lakes and wetlands [16 - 18] Thulborn's study improved the adjustment factor to predict the effect of urbanization on the flood frequency curve [19]; Miller proved that the relative increase in peak flows and reduction in flood duration and response time of a catchment is greatest at low levels of urbanization [20]; and Qin investigated water quality deterioration over the rapid urbanization in Shenzhen River catchment [21]. Liu, Jet and Du illustrated the effects of land use change on the quantity and quality of urban water resources using RS and GIS [22 - 24].

In spite of the above mentioned, there are still some lacks in the research about urban surface water area changes. Firstly, the studied area in most of the previous researches was usually considered as a catchment instead of a city. Secondly, the spatial scale difference of LUCC with location was usually ignored. In order to overcome these shortages, this paper tries to quantitatively investigate the area change of surface water bodies in Wuhan, China by RS and GIS. And the effect of spatial scale of land use on surface water bodies is discussed.

The main works of this paper are organized as follows: (1) to extract surface water bodies and land use classifications from Landsat TM/ETM+ images; (2) to compare the surface of water bodies in different periods and measure transformations from the reduced water area; (3) to measure land use changes in the riparian buffer zones; (4) and finally, to compare urban development in the different distances of riparian buffer zones.

\section{MATERIALS AND METHODOLOGY}

\section{Study Area and Data Sources}

Wuhan $\left(113^{\circ} 41^{\prime}-115^{\circ} 05^{\prime} \mathrm{E}, 2^{\circ} 58^{\prime}-31^{\circ} 22^{\prime} \mathrm{N}\right)$ is located in Central China, and is the capital of Hubei province. It lies in the eastern Jianghan Plain. And the Yangtze River and Han River intersect here. Wuhan is one of the biggest cities in China. The total area of Wuhan is $8494.14 \mathrm{~km}^{2}$. As shown in the Fig. (1), there are 13 districts in Wuhan, seven central districts such as Jiang'an District are regarded as urban area, and the rest of them are considered as suburban area. The urban area is totally $888.42 \mathrm{~km}^{2}$, which accounts for approximately $10 \%$ of total area. On the other hand, according to Wuhan Statistical Yearbook in 2006, as of 2005, the total population was over 8580000 persons, and 5317000 persons of them lived in the urban area. So, the average population density in the urban area is 5984 person per $\mathrm{km}^{2}$, even over 20000 person per $\mathrm{km}^{2}$ in some central districts. It is considerably higher than 429 person per $\mathrm{km}^{2}$ in the suburban area.

Wuhan has a subtropical monsoon climate with abundant rainfall and four distinctive seasons. The annual average precipitation is $1315.8 \mathrm{~mm}$ (1951-2013). And the Yangtze River and Han River intersect here as well. So, Wuhan has plentiful fresh water resources. There is approximately a quarter of the city covered by water bodies. But since the 1990s, with the rapid development of economy, the urban area has expanded significantly. The expansion of urban land led to irretrievable damages for water resources. Especially, filling in the lakes due to the development of real estate industry caused serious damage to surface water in Wuhan. A few lakes have even disappeared. A statistical result showed that 89 lakes had vanished away completely since the 1950s [26].

In this paper, surface water bodies in Wuhan are detected from Landsat images in 1991 and 2005 respectively (Table 1). During this period, the sharp growth of population led to the rapid development of real estate industry. Residences and commercial facilities had sprung up in Wuhan. And industries had been reconstructed. At the same time, the legislation for protection of surface water resources was not perfect yet. Therefore, the effect of urbanization on surface water bodies is typical during 1991and 2005. And according to the data from the National Climate Center of China, the accumulated precipitation before the image acquisition was 872 and 816 respectively, which showed that there was a similar nature condition in these two years. 


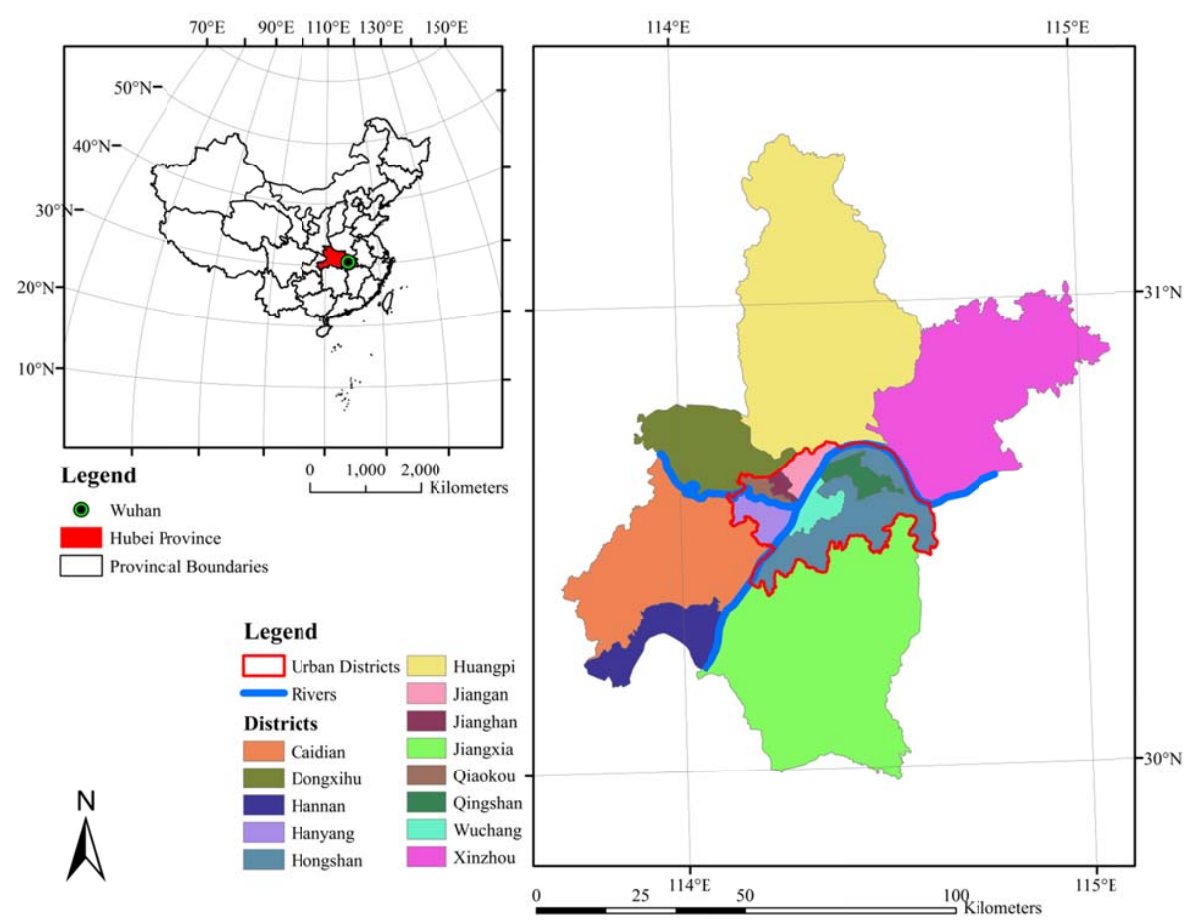

Fig. (1). Location and administrative divisions of Wuhan [25].

Table 1. Parameters of Landsat TM/ETM+ images.

\begin{tabular}{|c|c|c|}
\hline Date & Sensor & Spatial Resolution \\
\hline 1991.7 .19 & TM & $30 \mathrm{~m}$ (Band 1-5 and Band 7) \\
\hline 2005.9 .11 & ETM+ & $30 \mathrm{~m}$ (Band 1-5 and Band 7) \\
\hline
\end{tabular}

\section{Detection of Surface Water and Land Use Classification}

The spectral characteristic of water is decreasing with wavelength. Thus surface water bodies is usually detected from Landsat images by Normalized Difference Water Index (NDWI) as Equation (1) [27]:

$$
N D W I=\frac{B 2-B 4}{B 2+B 4}
$$

$\mathrm{Xu}$ [28] indicated that using NDWI is often mixed with built-up land noise. And the modified NDWI (MNDWI) as Equation (2) can enhance surface water bodies while suppressing and even removing built-up land noise as well as vegetation and soil noise.

$$
M N D W I=\frac{B 2-B 5}{B 2+B 5}
$$

Fig. (2) shows extracted surface water bodies using NDWI and MNDWI respectively. MNDWI can surely suppress built-up land noise and enhance water bodies in Fig. (2b).

According to spectral characteristic, land use is divided into 6 categories as shown in Table 2. The reflectivity of each category was sampled and drawn in Fig. (3). Apart from the surface water bodies extracted by MNDWI, riparian land use was classified using ISODATA, which is a kind of cluster algorithm based on minimum spectral distance [29]. The ISODATA is a modification of the k-means clustering algorithm. In an iteration cycle, clusters are merged if their distance in multispectral feature space is less than a specified value; and a single cluster is split into two new clusters if its variance is larger than a specified value. The algorithm repeats these procedures until specified result is obtained or maximum number of iterations is reached. The ISODATA is the default method of unsupervised classification in Erdas Imagine software. So land use maps of Wuhan in 1991 and 2005 have been drawn by Erdas Imagine software as Fig. (4). 


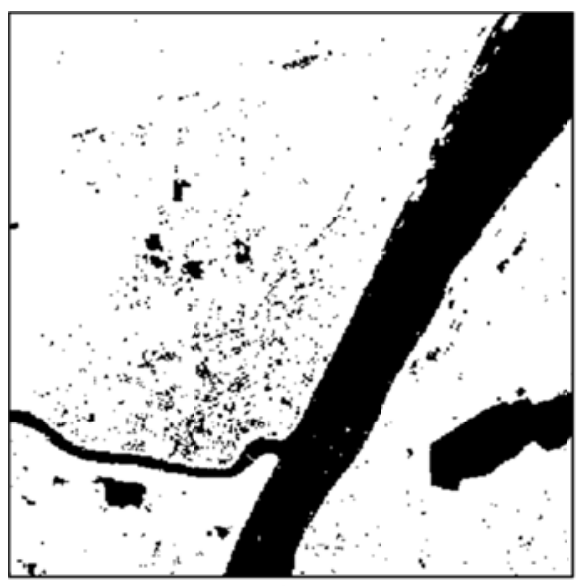

(a)

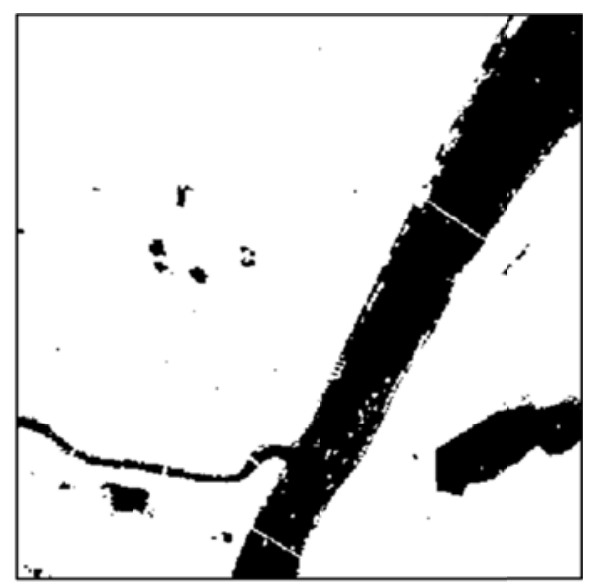

(b)

Fig. (2). Extractions of surface water bodies by (a) NDWI and (b) MNDWI.

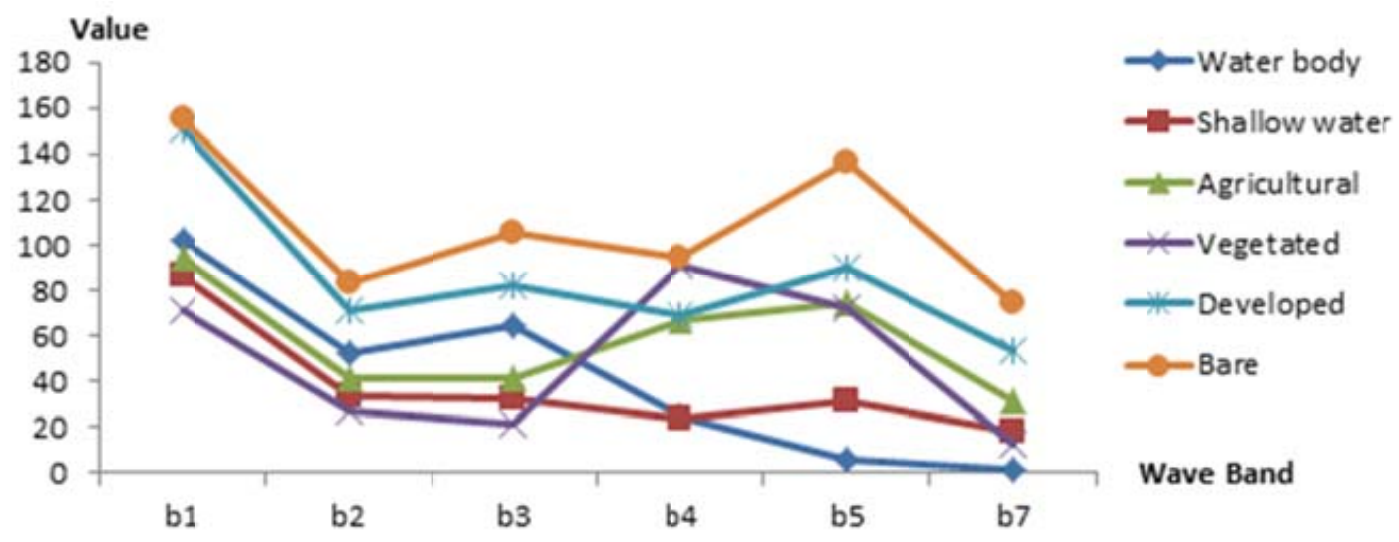

Fig. (3). Curves of spectral characteristics by sampling each category on each band.
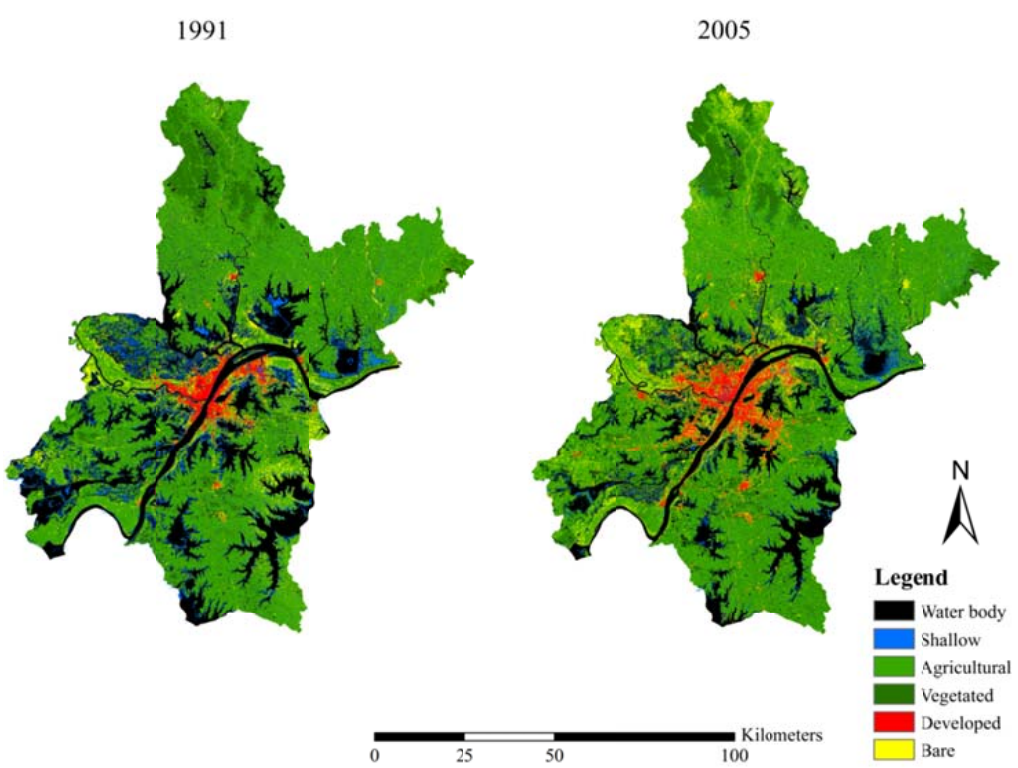

Fig. (4). Land use maps of Wuhan in 1991 and 2005. 
Table 2. Land use classifications [25].

\begin{tabular}{|c|c|}
\hline Category & Remarks \\
\hline Water body & Surface water bodies: rivers, lakes and ponds \\
\hline Shallow water & Edge of water bodies: wetlands \\
\hline Agricultural & Dry land and paddy fields \\
\hline Vegetated & Nature forests and grasslands \\
\hline Developed & Artificial areas: residential, commercial and industrial areas \\
\hline Bare & Bare surfaces: bare lands and construction sites \\
\hline
\end{tabular}

\section{Measurement of Surface Water Bodies and Riparian Land Use Changes}

In the ArcGIS software, spatial analysis tools such as overlap analysis and buffer analysis are applied to measure surface water bodies and their surrounding land use changes. There are three phases in this study.

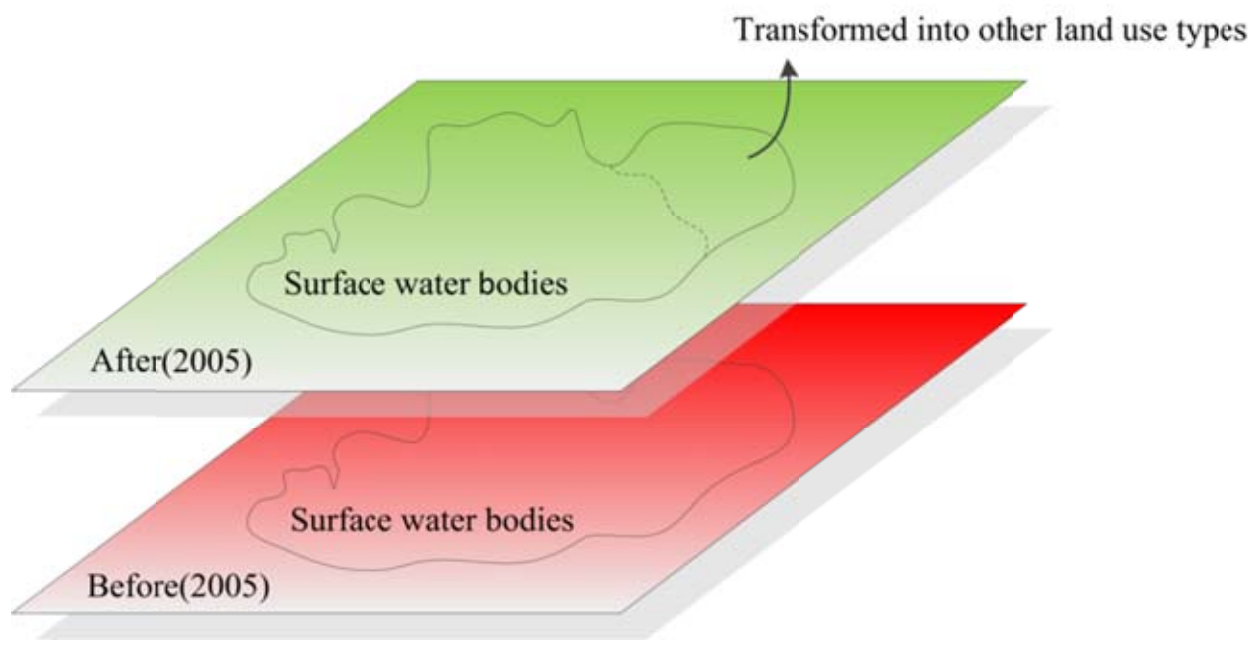

Fig. (5). Detection of surface water bodies during 1991 and 2005 using overlay analysis.

Firstly, extracted surface water bodies in 1991 and 2005 are compared to each other by overlap analysis as Fig. (5). Particularly, the decrement of surface water bodies during this period is calculated quantitatively. In order to indicate whether the decrement of surface water bodies is related with urbanization or not, the transformation of these reduced water bodies into other laud use types is detected. If most of reduced water bodies had been changed into developed land during this period, it can prove that urban development occupied surface water areas as urbanization. Then, the magnitude of each land use type from reduced water bodies is calculated with the districts as Fig. (1). If the decrement of surface water bodies is connected with urbanization, the spatial distributions of the transformation of reduced water bodies in the urban and suburban districts are different. In other word, reduced water bodies transformed into developed land in the urban districts are greater than in the suburban districts.

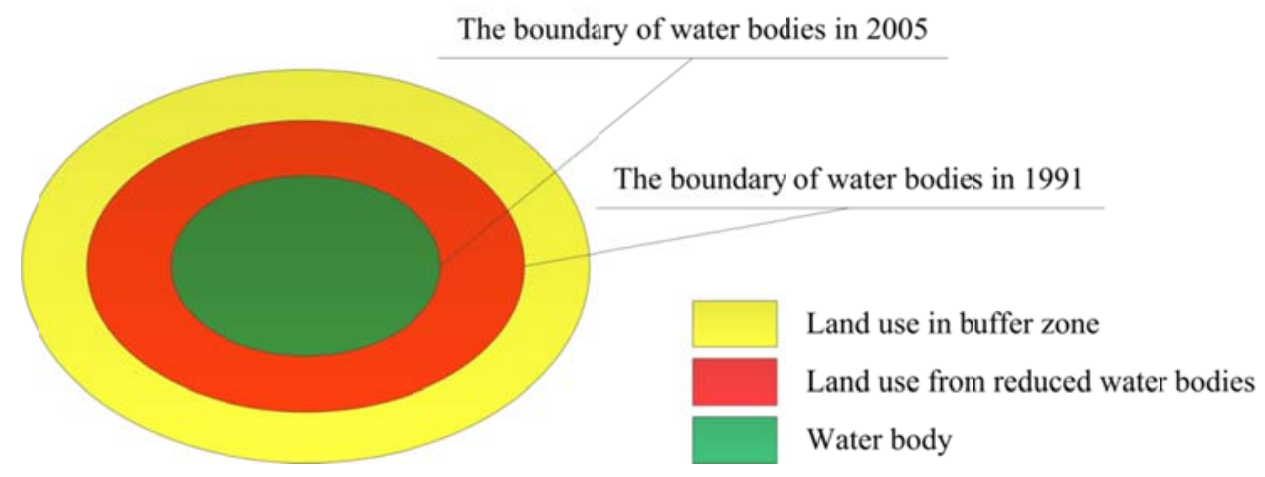

Fig. (6). To measure riparian land use changes in the buffer zone. 
Secondly, in order to measure riparian land use change as urbanization, as shown in Fig. (6), a riparian buffer zone with $100 \mathrm{~m}$ width is drawn around the boundary of water bodies in 1991 using buffer analysis in ArcGIS software. And land use changes in this buffer zone during 1991 and 2005 are calculated with the districts as Fig. (1). If the proportion of developed land in riparian was raised during this period, it can indicate that urban development is becoming increasingly active around surface water bodies.

Even if develop land was increased in riparian, it could be independent of surface water bodies. So, in order to investigate the relationships between surface water bodies and urban expansion, finally, a riparian buffer zone with $1000 \mathrm{~m}$ width is delineated around the boundary of water bodies in 1991. And the proportion of developed land in 1000 $\mathrm{m}$ buffer zone is compared with it in $100 \mathrm{~m}$ buffer zone. It can indicate that the urban expansion is growing towards surface water bodies and compress the space of surface water bodies if the growth of developed land in $100 \mathrm{~m}$ buffer zone is faster than in $1000 \mathrm{~m}$ buffer zone.

\section{RESULTS AND DISCUSSIONS}

\section{Decrement of Surface Water Bodies and their Transformations}

Surface water bodies in 1991 and 2005are extracted respectively as shown in Fig. (7a, b). There is an obvious decrement of surface water bodies in Wuhan during this period. In 1991, surface water bodies covered 20\% of Wuhan and even $29 \%$ in the urban area. In 2005, the proportion of surface water bodies had been reduced to $15 \%$ and $22 \%$ in Wuhan and its urban area respectively. In other words, the decrement of surface water bodies in the urban area was more than in the suburban area. And it is validated as shown in Fig. (7c). Two of urban districts, Jiangan District and Hongshan District, had the greatest loss rate of $10.2 \%$ in the urban area. Note that about $14 \%$ of surface water bodies had been covered by other land use types in CaiDian District, which is even greater than any district in the urban area. It is possible that Wuhan Economic and Technological Development Zone has been developed since 1991.

The transformation of reduced surface water bodies is listed as Table 3. In the suburban area, most of reduced surface water bodies transformed into agricultural land (37\%). And only $7.25 \%$ of reduced water area had been used to developed land after they were covered. And in the urban area, about $24 \%$ of reduced surface water bodies changed into developed land as well as agricultural and vegetated land. On the one hand, water resources conservation has been valued in Wuhan since the 2000s. So there are greenbelts in riparian zones to isolate water bodies from human activities. On the other hand, agricultural land is still main land use type in the edge of urban area.

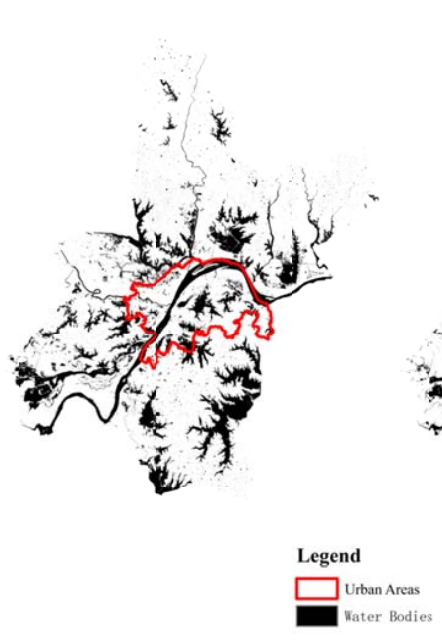

(a)

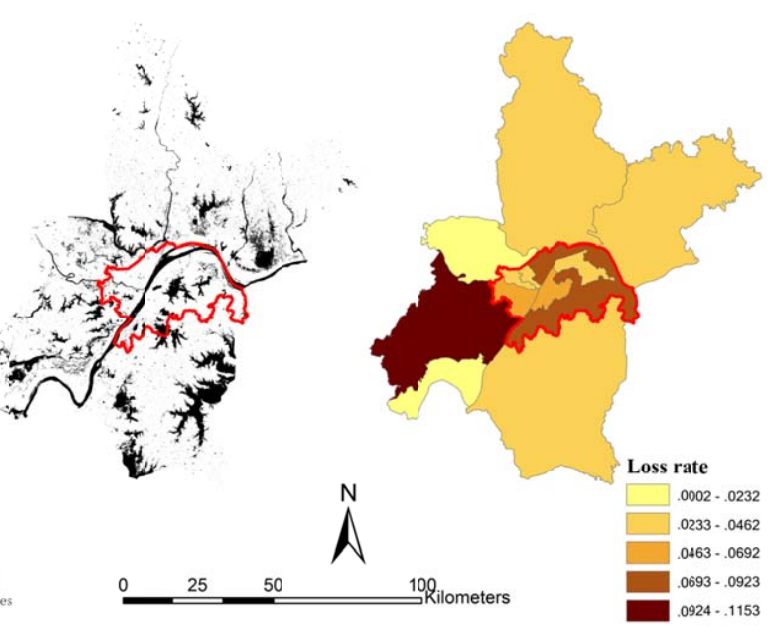

(b)

(c)

Fig. (7). Surface water bodies (a) In 1991 and (b) 2005; and (c) The spatial distribution of loss rate. 
Table 3. Transformations of reduced water bodies into other land use types.

\begin{tabular}{|c|c|c|c|c|c|c|}
\hline \multirow{2}{*}{ Category } & \multirow{2}{*}{ District Name } & \multicolumn{5}{|c|}{ Transformation (\%) } \\
\hline & & Shallow Water & Agricultural & Vegetated & Developed & Bare \\
\hline \multirow{8}{*}{ Urban } & HANYANG & 18.74 & 31.51 & 25.07 & 19.75 & 4.93 \\
\hline & WUCHANG & 12.81 & 10.81 & 16.06 & 47.96 & 12.36 \\
\hline & QIAOKOU & 16.73 & 25.75 & 32.82 & 20.97 & 3.72 \\
\hline & JIANGHAN & 8.82 & 3.54 & 7.22 & 69.21 & 11.21 \\
\hline & QINGSHAN & 18.31 & 28.62 & 24.81 & 24.48 & 3.77 \\
\hline & HONGSHAN & 19.75 & 25.35 & 26.76 & 18.83 & 9.3 \\
\hline & JIANG'AN & 13.07 & 15 & 17.54 & 41.85 & 12.53 \\
\hline & Average & 18.21 & 24.16 & 24.79 & 24.11 & 8.73 \\
\hline \multirow{7}{*}{ Rural } & HANNAN & 28.50 & 41.96 & 17.95 & 10.45 & 1.14 \\
\hline & JIANGXIA & 35.19 & 36.84 & 16.47 & 9.05 & 2.46 \\
\hline & CAIDIAN & 18.81 & 43.37 & 25.41 & 4.53 & 7.88 \\
\hline & DONGXIHU & 19.19 & 32.7 & 27.8 & 13.7 & 6.6 \\
\hline & XINZHOU & 28.02 & 31.57 & 27.06 & 8.28 & 5.07 \\
\hline & HUANGPI & 27.53 & 36.19 & 22.21 & 6.03 & 8.04 \\
\hline & Average & 26.41 & 37.43 & 23.01 & 7.25 & 5.89 \\
\hline
\end{tabular}

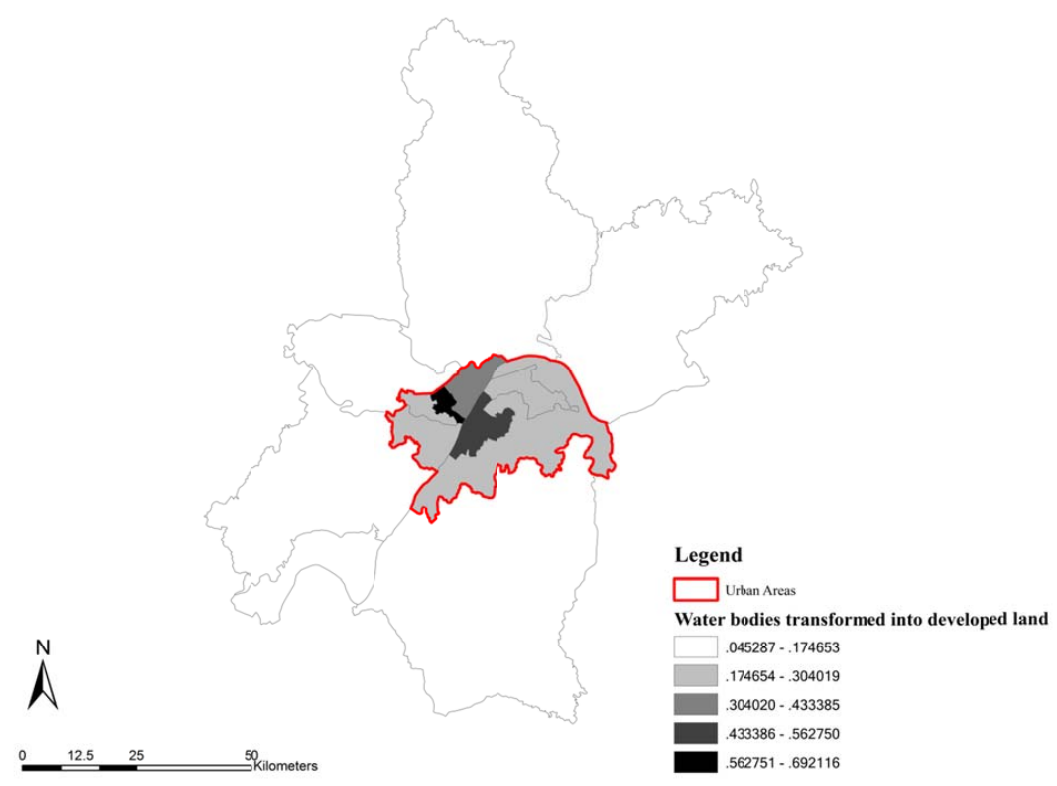

Fig. (8). Spatial distribution of the transformation of reduced surface water bodies into developed land.

According to Table 3, the spatial distribution of the transformation of reduced surface water bodies into developed land could be drawn as Fig. (8). As shown, in the urban area, reduced water bodies were more likely to transform into developed land than in the suburban area. Particularly $69 \%$ of reduced water area had been used to commercial land or residential land in Jianghan District, the most prosperous district in Wuhan. Therefore, there is a correlation between surface water area change and urbanization.

\section{Land Use Change in Buffer of Surface Water Bodies}

Table 4 lists the proportion of each land use type in $100 \mathrm{~m}$ buffer of surface water bodies. As shown, the proportion of developed land in the urban area had been raised from $15.9 \%$ to $29.9 \%$ during 1991 and 2005 , as well as bare land that had been raised from $2.5 \%$ to $11.7 \%$. On the other hand, both these two land use types had slight and even negative growth in the suburban area. 
Table 4. The proportion of each land use classification in $100 \mathrm{~m}$ buffer of surface water bodies.

\begin{tabular}{|c|c|c|c|c|c|c|c|}
\hline \multirow{2}{*}{ Category } & \multirow{2}{*}{ District Name } & \multirow{2}{*}{ Year } & \multicolumn{5}{|c|}{ Percentage (\%) } \\
\hline & & & Shallow & Agricultural & Vegetated & Developed & Bare \\
\hline \multirow{16}{*}{ Urban } & \multirow{2}{*}{ HANYANG } & 1991 & 45.51 & 26.29 & 7.64 & 17.37 & 3.19 \\
\hline & & 2005 & 11.29 & 25.67 & 23.66 & 29.13 & 10.26 \\
\hline & \multirow{2}{*}{ WUCHANG } & 1991 & 37.99 & 22.37 & 2.03 & 34.55 & 3.05 \\
\hline & & 2005 & 7.55 & 10.82 & 8.33 & 65.63 & 7.67 \\
\hline & \multirow{2}{*}{ QIAOKOU } & 1991 & 51.39 & 19.02 & 02.43 & 25.63 & 1.54 \\
\hline & & 2005 & 8.45 & 18.60 & 24.93 & 36.68 & 11.33 \\
\hline & \multirow{2}{*}{ JIANGHAN } & 1991 & 35.56 & 20.86 & 2.91 & 37.26 & 3.41 \\
\hline & & 2005 & 5.06 & 2.37 & 6.67 & 74.75 & 11.15 \\
\hline & \multirow{2}{*}{ QINGSHAN } & 1991 & 51.23 & 26.06 & 4.9 & 15.55 & 1.72 \\
\hline & & 2005 & 12.53 & 28.26 & 21.77 & 32.84 & 4.6 \\
\hline & \multirow{2}{*}{ HONGSHAN } & 1991 & 46.9 & 33.19 & 7.63 & 9.77 & 2.52 \\
\hline & & 2005 & 10.68 & 28.98 & 27.69 & 20 & 12.66 \\
\hline & \multirow{2}{*}{ JIANG'AN } & 1991 & 42.62 & 21.06 & 8.26 & 25.99 & 2.07 \\
\hline & & 2005 & 5.57 & 12.57 & 19.52 & 43.85 & 18.49 \\
\hline & \multirow{2}{*}{ Average } & 1991 & 46.06 & 28.74 & 6.75 & 15.93 & 2.52 \\
\hline & & 2005 & 10.03 & 24.56 & 23.84 & 29.91 & 11.66 \\
\hline \multirow{14}{*}{ Rural } & \multirow{2}{*}{ HANNAN } & 1991 & 46.37 & 30.93 & 14.79 & 6.45 & 1.46 \\
\hline & & 2005 & 19.9 & 44.47 & 20.61 & 5.97 & 9.05 \\
\hline & \multirow{2}{*}{ JIANGXIA } & 1991 & 37.2 & 33.54 & 14.28 & 4.58 & 10.4 \\
\hline & & 2005 & 8.24 & 41.71 & 21.34 & 7.88 & 20.83 \\
\hline & \multirow{2}{*}{ CAIDIAN } & 1991 & 45.9 & 33.24 & 10.06 & 6.53 & 4.27 \\
\hline & & 2005 & 8.75 & 45.28 & 24.26 & 6.98 & 14.73 \\
\hline & \multirow{2}{*}{ DONGXIHU } & 1991 & 52.46 & 25.45 & 6.4 & 13.41 & 2.28 \\
\hline & & 2005 & 13.15 & 40.73 & 22.11 & 12.15 & 11.87 \\
\hline & \multirow{2}{*}{ XINZHOU } & 1991 & 29.81 & 28.82 & 16.99 & 8.73 & 15.65 \\
\hline & & 2005 & 13.91 & 49.25 & 27.6 & 5.31 & 13.93 \\
\hline & \multirow{2}{*}{ HUANGPI } & 1991 & 24.84 & 37.73 & 15.63 & 6.18 & 15.62 \\
\hline & & 2005 & 9.37 & 40.81 & 27.26 & 3.63 & 18.94 \\
\hline & \multirow{2}{*}{ Average } & 1991 & 35.66 & 32.93 & 13.76 & 6.94 & 10.7 \\
\hline & & 2005 & 10.46 & 41.61 & 24.65 & 6.38 & 16.89 \\
\hline
\end{tabular}

Tables 5 and 6 list the land use transfer matrixes of the $100 \mathrm{~m}$ buffer during 1991 and 2005 in the urban and suburban areas respectively. According to Tables $\mathbf{5}$ and $\mathbf{6}$, shallow water and agricultural land are the main inputs in the urban area as well as in the suburban area. However the main outputs in Tables $\mathbf{5}$ and $\mathbf{6}$ are different: developed land $(31.9 \%)$ is the most output in the urban area; and vegetated (34.6\%) and agricultural $(31.6 \%)$ land are the main output in the suburban area. Therefore, with urbanization, the wetlands in the waterside would be developed.

Table 5. The land use transition matrix of $100 \mathrm{~m}$ buffer of surface water bodies in the urban area.

\begin{tabular}{|c|c|c|c|c|c|c|}
\hline Input Output (\%) & Shallow Water & Agricultural & Vegetated & Developed & Bare & Total Input \\
\hline Shallow Water & 7.191911 & 10.55486 & 9.471465 & 12.59442 & 3.296413 & 43.10907 \\
\hline Agricultural & 1.642699 & 8.71441 & 8.85397 & 7.275798 & 3.74077 & 30.22765 \\
\hline Vegetated & 0.210793 & 1.413129 & 2.492882 & 1.58613 & 1.516723 & 7.219658 \\
\hline Developed & 0.921922 & 1.625604 & 2.517753 & 9.418678 & 2.255183 & 16.73914 \\
\hline Bare & 0.062835 & 0.207085 & 0.502591 & 1.077401 & 0.854577 & 2.70449 \\
\hline Total Output & 10.03016 & 22.55509 & 23.83866 & 31.91243 & 11.66367 & 100 \\
\hline
\end{tabular}

Table 6. The land use transition matrix of $100 \mathrm{~m}$ buffer of surface water bodies in the suburban area.

\begin{tabular}{|c|c|c|c|c|c|c|}
\hline Input|Output (\%) & Shallow Water & Agricultural & Vegetated & Developed & Bare & Total Input \\
\hline Shallow Water & 6.087833 & 12.02253 & 8.590296 & 2.398836 & 2.382144 & 31.48164 \\
\hline
\end{tabular}


(Table 6) contd.....

(Table 6) contd.....
\begin{tabular}{|c|c|c|c|c|c|c|}
\hline Input Output (\%) & Shallow Water & Agricultural & Vegetated & Developed & Bare & Total Input \\
\hline Agricultural & 2.538382 & 12.58757 & 13.18718 & 1.739684 & 4.854365 & 34.90718 \\
\hline Vegetated & 0.600363 & 3.961423 & 6.452917 & 0.595055 & 3.338526 & 14.94828 \\
\hline Developed & 0.7781 & 1.758779 & 2.091873 & 1.117736 & 1.372147 & 7.118634 \\
\hline Bare & 0.459812 & 1.283448 & 4.325935 & 0.531811 & 4.943257 & 11.54426 \\
\hline Total Output & 10.46449 & 31.61375 & 34.6482 & 6.383122 & 16.89044 & 100 \\
\hline
\end{tabular}

Table 7 shows the proportions of developed land in $100 \mathrm{~m}$ and $1000 \mathrm{~m}$ buffers respectively. In the suburban area, developed land is negligible both in $100 \mathrm{~m}$ and $1000 \mathrm{~m}$ buffers. However, it is obviously increased both in $100 \mathrm{~m}$ and $1000 \mathrm{~m}$ buffers in the urban area. It is worth noting that although $33.3 \%$ of developed land in $100 \mathrm{~m}$ buffer is smaller than $42.1 \%$ in $1000 \mathrm{~m}$ buffer, about $14 \%$ of the increment of developed land in $100 \mathrm{~m}$ buffer is larger than $8.8 \%$ in 1000 $\mathrm{m}$ buffer. Therefore, Table 7 indicates that the growth of developed land in $100 \mathrm{~m}$ buffer is faster than in $1000 \mathrm{~m}$ buffer. In other words, urban expansion is growing towards surface water bodies so that it tends to compress the space of surface water bodies with urbanization.

Table 7. The proportions of developed land in $100 \mathrm{~m}$ and $1000 \mathrm{~m}$ buffers.

\begin{tabular}{|c|c|c|c|c|c|c|}
\hline & \multicolumn{3}{|c|}{ Buffer Distance $=\mathbf{1 0 0 m}$} & \multicolumn{3}{c|}{ Buffer Distance = 1000m } \\
\cline { 2 - 6 } & $\mathbf{1 9 9 1}$ & $\mathbf{2 0 0 5}$ & Increment & $\mathbf{1 9 9 1}$ & $\mathbf{2 0 0 5}$ & \multicolumn{1}{|c|}{ Increment } \\
\hline Urban & $15.93 \%$ & $29.91 \%$ & $13.98 \%$ & $33.31 \%$ & $42.12 \%$ & $8.81 \%$ \\
\hline Suburban & $6.94 \%$ & $6.38 \%$ & $-0.56 \%$ & $4.1 \%$ & $3.19 \%$ & $-0.91 \%$ \\
\hline
\end{tabular}

\section{CONCLUSION}

In this paper, surface water bodies and land use classifications were extracted from Landsat TM/ETM+ images of Wuhan in 1991 and 2005 respectively. An overlap analysis based on GIS proved that surface water bodies in Wuhan had been reduced during this period as urbanization. By measuring the transformations of reduced water area and riparian land use changes, the main effects of urbanization on surface water bodies could be summarized as follows: (1) surface water bodies is likely to be covered by developed land with urbanization; (2) the space of surface water bodies is compressed by urban expansion.

Therefore, in order to protect surface water resources, it is necessary to enhance the supervision of surface water bodies and isolate them from urban development by wetlands or greenbelts. Since the 2000s, the Wuhan government made some regulations for water resources conservation to preserve the ecosystem of rivers, lakes and wetlands, including their surrounding land utilizations. The practices of Wuhan could provide a reference for urban surface water resources conservation.

\section{INDEX OF ABBREVIATION}

\begin{tabular}{|l|l|}
\hline Abbreviation & English \\
\hline CBERS & China-Brazil earth resource satellite \\
\hline ETM & Enhanced thematic mapper \\
\hline HJ & Huanjing (pinyin, translated as environment) \\
\hline ISODATA & Iterative selforganizing data analysis techniques algorithm \\
\hline MNDWI & Modified normalized difference water index \\
\hline TM & Thematic mapper \\
\hline
\end{tabular}

\section{CONFLICT OF INTEREST}

The authors confirm that this article content has no conflict of interest.

\section{ACKNOWLEDGEMENTS}

This study was supported by the Natural Science Foundation of Hubei Province, China (2015CFA134) and the National Natural Science Foundation of China (41072199). 


\section{REFERENCES}

[1] B. Han, "History and Future of Urbanization in China", J. of Xi'an Jiaotong Uni. (Social Sci.), vol. 31, pp. $18-22,2011$.

[2] P.M. Groffman, D.J. Bain, L.E. Band, K.T. Belt, G.S. Brush, and J.M. Grove, "Down by the riverside: urban riparian ecology", Front. Ecol. Environ, vol. 1, pp. 315-321, 2003. [http://dx.doi.org/10.1890/1540-9295(2003)001[0315:DBTRUR]2.0.CO;2]

[3] J.G. Lee, and J.P. Heaney, "Estimation of urban imperviousness and its impacts on storm water systems", J. Water Resour. Plan. Manage., vol. 129, pp. 419-426, 2003. [http://dx.doi.org/10.1061/(ASCE)0733-9496(2003)129:5(419)]

[4] A. Abrishamchi, A. Ebrahimian, M. Tajrishi, and M.A. Mariño, "Case study: application of multicriteria decision making to urban water supply", J. Water Resour. Plan. Manage., vol. 131, pp. 326-335, 2005.

[http://dx.doi.org/10.1061/(ASCE)0733-9496(2005)131:4(326)]

[5] G. Xian, M. Crane, and J. Su, "An analysis of urban development and its environmental impact on the Tampa Bay watershed", J. Environ. Manage., vol. 85, no. 4, pp. 965-976, 2007. [http://dx.doi.org/10.1016/j.jenvman.2006.11.012] [PMID: 17208348]

[6] J. Wang, L. Da, K. Song, and B-L. Li, "Temporal variations of surface water quality in urban, suburban and rural areas during rapid urbanization in Shanghai, China", Environ. Pollut., vol. 152, no. 2, pp. 387-393, 2008. [http://dx.doi.org/10.1016/j.envpol.2007.06.050] [PMID: 17681654]

[7] J.H. Jiang, H.S. Dou, and Q. Huang, "Relational analysis of the features of resources and functions of lakes", J. Natural Resour., vol. 19, pp. 386-391, 2004.

[8] Z. Zheng, W. Yang, G. Zhou, and X. Wang, "Analysis of land use and cover change in Sichuan province, China", J. Appl. Remote Sens., vol. 6, p. 063587, 2012.

[http://dx.doi.org/10.1117/1.JRS.6.063587]

[9] P. Du, J. Xia, and L. Feng, "Monitoring urban impervious surface area change using China-Brazil Earth Resources Satellites and HJ-1 remote sensing images", J. Appl. Remote Sens., vol. 9, p. 093094, 2015. [http://dx.doi.org/10.1117/1.JRS.9.096094]

[10] S. Abdullahi, B. Pradhan, S. Mansor, and A.R. Shariff, "GIS-based modeling for the spatial measurement and evaluation of mixed land use development for a compact city", GIsci. Remote Sens., vol. 52, pp. 18-39, 2015. [http://dx.doi.org/10.1080/15481603.2014.993854]

[11] B.S. Razavi, "Predicting the trend of land use changes using artificial neural network and markov chain model (Case Study: Kermanshah City)", Res. J. Environ. Earth Sci., vol. 6, pp. 215-226, 2014.

[12] V.H. Dale, R.A. Efroymson, and K.L. Kline, "The land use-climate change-energy nexus", Landscape Ecol., vol. 26, pp. 755-773, 2011. [http://dx.doi.org/10.1007/s10980-011-9606-2]

[13] X. Deng, C. Zhao, and H. Yan, "Systematic modeling of impacts of land use and land cover changes on regional climate: a review", Adv. Meteorol., vol. 2013, pp. 1375-1383, 2013. [http://dx.doi.org/10.1155/2013/317678]

[14] S. Lei, and Z. Tian, "Research on the relationship between Urban Heat Island and LUCC in Xuzhou city by remote sensing", In: Remote Sensing, Environment and Transportation Engineering (RSETE), 2011 International Conference, 2011, pp. 2436-2439.

[15] H. Radhi, F. Fikry, and S. Sharples, "Impacts of urbanisation on the thermal behaviour of new built up environments: A scoping study of the urban heat island in Bahrain", Landsc. Urban Plan., vol. 113, pp. 47-61, 2013. [http://dx.doi.org/10.1016/j.landurbplan.2013.01.013]

[16] P. Huang, Y. Liu, C. Liu, and Q. Jiang, "Study on evolution of urban lakes in Wuhan based on RS/GIS", Ecol. Envir. Sci., vol. 21, pp. 1588-1593, 2012.

[17] M. Hettiarachchi, T.H. Morrison, D. Wickramsinghe, R. Mapa, A. De Alwis, and C.A. McAlpine, "The eco-social transformation of urban wetlands: A case study of Colombo, Sri Lanka", Landsc. Urban Plan., vol. 132, pp. 55-68, 2014. [http://dx.doi.org/10.1016/j.landurbplan.2014.08.006]

[18] M. Chen, J.C. Rowland, C.J. Wilson, G.L. Altmann, and S.P. Brumby, "Temporal and spatial pattern of thermokarst lake area changes at Yukon Flats, Alaska", Hydrol. Processes, vol. 28, pp. 837-852, 2014. [http://dx.doi.org/10.1002/hyp.9642]

[19] K.R. Thulborn, B. Mccurtain, J. Voyvodic, S. Chang, J. Gillen, and J.A. Sweeney, "Modelling the impact of urbanization on flood frequency relationships in the UK", Hydrol. Res., vol. 41, pp. 391-405, 2010. [http://dx.doi.org/10.2166/nh.2010.056]

[20] J.D. Miller, H. Kim, T.R. Kjeldsen, J. Packman, S. Grebby, and R. Dearden, "Assessing the impact of urbanization on storm runoff in a periurban catchment using historical change in impervious cover", J. Hydrol. (Amst.), vol. 515, pp. 59-70, 2014. [http://dx.doi.org/10.1016/j.jhydrol.2014.04.011]

[21] H. Qin, Q. Su, S.T. Khu, and N. Tang, "Water quality changes during rapid urbanization in the shenzhen river catchment: an integrated view of socio-economic and infrastructure development", Sustainability, vol. 6, pp. 7433-7451, 2014. 
[http://dx.doi.org/10.3390/su6107433]

[22] Y. Liu, X. Lv, X. Qin, H. Guo, Y. Yu, and J. Wang, "An integrated GIS-based analysis system for land-use management of lake areas in urban fringe", Landsc. Urban Plan., vol. 82, pp. 233-246, 2007.

[http://dx.doi.org/10.1016/j.landurbplan.2007.02.012]

[23] M.K. Jat, D. Khare, P.K. Garg, and V. Shankar, "Remote sensing and GIS-based assessment of urbanisation and degradation of watershed health", Urban Water J., vol. 6, pp. 251-263, 2009.

[http://dx.doi.org/10.1080/15730620801971920]

[24] N. Du, H. Ottens, and R. Sliuzas, "Spatial impact of urban expansion on surface water bodies-A case study of Wuhan, China", Landsc. Urban Plan., vol. 94, pp. 175-185, 2010.

[http://dx.doi.org/10.1016/j.landurbplan.2009.10.002]

[25] J. Zhu, Q. Zhang, and Z. Tong, "Impact analysis of lakefront land use changes on lake area in wuhan, china", Water, vol. 7, pp. 4869-4886, 2015.

[http://dx.doi.org/10.3390/w7094869]

[26] Z. Wang, "Study on Protection and Utilization of Wuhan City Lake since 1990s", Environ. Sci. Manag., vol. 38, pp. 38-45, 2013.

[27] S. K. Mcfeeters, "The use of Normalised Difference Water Index (NDWI) in the delineation of open water features", Int. J. Remote Sens., vol. 17, pp. 1425-1432, 1996. [http://dx.doi.org/10.1080/01431169608948714]

[28] H. Xu, "Modification of normalised difference water index (NDWI) to enhance open water features in remotely sensed imagery", Int. $J$. Remote Sens., vol. 27, pp. 3025-3033, 2006.

[http://dx.doi.org/10.1080/01431160600589179]

[29] B.J. Irvin, S.J. Ventura, and B.K. Slater, "Fuzzy and isodata classification of landform elements from digital terrain data in Pleasant Valley, Wisconsin", Geoderma, vol. 77, pp. 137-154, 1997. [http://dx.doi.org/10.1016/S0016-7061(97)00019-0]

(C) Zhu et al.; Licensee Bentham Open

This is an open access article licensed under the terms of the Creative Commons Attribution-Non-Commercial 4.0 International Public License (CC BY-NC 4.0) (https://creativecommons.org/licenses/by-nc/4.0/legalcode), which permits unrestricted, non-commercial use, distribution and reproduction in any medium, provided the work is properly cited. 